\title{
OBECNOŚĆ PROBLEMU PREKARIATU I PREKARYJNEJ PRACY W POLITYCE SPOŁECZNEJ
}

\author{
THE PRESENCE OF THE PRECARIAT PROBLEM AND PRECARIAT \\ WORK IN SOCIAL POLICY
}

Katarzyna Zamorska* ๑)

\begin{abstract}
ABSTRAKT
Jedną z konsekwencji odejścia od etatowej pracy jest obniżenie poczucia bezpieczeństwa socjalnego wśród pracowników, których określa się mianem prekariatu, a wykonywane przez nich prace jako niepewne (prekarne). W artykule, w nawiązaniu do dyskusji w środowisku naukowym, toczącym się co najmniej od lat 80. XX w., skupiam uwagę na dwóch aspektach zagadnienia: niepewności przypisywanej do obecnie wykonywanej pracy zawodowej oraz roli polityki społecznej i jej instytucji w kreowaniu prekarnych miejsc pracy. Wykorzystuję metodę porównawczą, sięgając do prac, których autorzy piszą o prekariacie w sposób bezpośredni lub gdzie stanowi on kontekst wypowiedzi o rzeczywistości społecznej. $\mathrm{W}$ ten sposób zamierzam pozyskać znaczenie i treść pojęcia prekariat.
\end{abstract}

Słowa kluczowe: bezpieczeństwo socjalne; kwestia społeczna; polityka społeczna; prekaria; niepewna praca
One of the consequences of moving away from full-time work is lowering the sense of social security among employees, who are referred to as precariat, and their work as uncertain (precarious). In the article, referring to the discussion present in the scientific community at least since the 1980s, I focus on two aspects of the issue: uncertainty attributed to the currently performed professional work and the role of social policy and its institutions in creating precarious jobs. I use the comparative method, referring to works of the authors who write about the precariat in a direct or indirect way, constituting the context of the statement about social reality. In this way, I intend to acquire the meaning and content of the term 'precariat'.

Keywords: social security; social issue; social policy; precariat; work insecurity

\footnotetext{
* Uniwersytet Wrocławski, Wydział Nauk Społecznych.
} 


\section{WSTĘP}

Przedmiotem artykułu jest kilka problemów związanych z odejściem od stałej etatowej pracy i wynikających z tego konsekwencji dla pracowników, wobec których stosuje się pojęcie prekariatu, a ich miejsca pracy określa jako prekarne. Sam termin odnosi się do sytuacji, w której pracownik pozbawiony jest tych wszystkich atrybutów, jakie zwykle przypisane są do pełnoetatowej pracy. Niepewność i brak poczucia bezpieczeństwa socjalnego są obecnie tymi określeniami, które dobrze opisują położenie coraz większej liczby pracowników, szczególnie zatrudnionych w tak zwanych atypowych formach pracy. Jednocześnie im bardziej to zjawisko zaczyna się kumulować, tym bardziej tego rodzaju praca zastępuje etat, stając się niejako normą, tym bardziej zaczyna stanowić wyzwanie dla krajowych polityk społecznych.

Odnosząc się zatem do zaproponowanej problematyki i mając także na uwadze toczący się dyskurs naukowy, proponuję zwrócić uwagę na dwa aspekty spośród wielu innych. Pierwszy będzie odnosił się do pojęcia niepewności, którą traktuję jako równoznaczne z prekarną pracą. Problem polega przede wszystkim na tym, że ze swej istoty niepewność jest trudna do zmierzenia, stąd nie zawsze w sposób precyzyjny określa sytuację w różnych grupach pracowniczych. $\mathrm{Na}$ przykład wśród pracowników o niskich i wysokich kwalifikacjach ocena sytuacji, wynikająca z prekaryjności w zatrudnieniu, może diametralnie się różnić. Drugi punkt sprowadzał się będzie do określenia roli, jaką polityka społeczna i jej instytucje odegrały w wykreowaniu prekariatu, a tym samym wpłynęły na tendencje rozszerzania się niepewnych miejsc pracy. Celem artykułu, przy tak sprecyzowanych zagadnieniach, jest podkreślenie zagrożeń, wynikających ze wzrostu niestabilnych form zatrudnienia. Stanowią one wyzwanie dla polityki społecznej.

Próbując zmierzyć się z zasygnalizowanym w tytule zagadnieniem, wykorzystuję metodę porównawczą. Sięgam do prac, których autorzy odnoszą się do prekariatu w sposób bezpośredni, lub tych, gdzie stanowi on kontekst wypowiedzi o rzeczywistości społecznej. W ten sposób zamierzam pozyskać znaczenie i treść pojęcia prekariat.

Złożony charakter podjętego w artykule zagadnienia wymagać jednak będzie, by w pierwszej kolejności przypomnieć okoliczności, które doprowadziły do wytworzenia prekariatu. Przyjmuję przy tym założenie, że prekariat (przez analogię także prekaryjna praca) i polityka społeczna to dwa pojęcia, będące w stosunku do siebie w opozycji. 


\section{OD BEZPIECZEŃSTWA SOCJALNEGO DO NIESTABILNEJ SYTUACJI PRACOWNIKÓW}

Twierdzę zatem, że prekariat, będący synonimem niepewności i braku poczucia bezpieczeństwa, jest zaprzeczeniem tego wszystkiego, co stanowi o racji bytu polityki społecznej; jest naruszeniem celów, zasad i wartości, na których ustanowiona została polityka społeczna. Co przemawia za przyjęciem takiego założenia? Po pierwsze zasady, które legły u podstaw polityki społecznej jako działalności praktycznej, co później znalazło swój wyraz w jej licznych definicjach. Nie wnikając w tym miejscu w zawiłości modelowe, wiele nie zaryzykuję, gdy stwierdzę, że polityka społeczna od samego początku (przełom XVIII i XIX w.) dążyła do poprawy położenia społecznego i gospodarczego osób słabych pod względem ekonomicznym (Lampert, 1998, s. 4). Po drugie na takie postawienie problemu pozwala dokonana przez Roberta Castela dokładna analiza stopniowych przeobrażeń, jakim został poddany status pracownika najemnego. Ogólnie rzecz ujmując, polityka społeczna miała zapewnić członkom społeczeństwa - jak ujął to twórca obywatelstwa społecznego Thomas H. Marshall - prawo do odrobiny (modicum) ekonomicznego dobrobytu i bezpieczeństwa (Marshall, 1950, s. 8), a w dalszej perspektywie - już obywatelom - optymalizację dystrybucji pomyślności (Esping-Andersen, 1999, s. 36). Cel osiągnąć miano zatem dzięki pełnemu zatrudnieniu $\mathrm{w}$ warunkach gospodarki rynkowej, w połączeniu $\mathrm{z}$ postulowaną ideą obywatelstwa, które spełnia się w prawie do wytwarzania, ale i korzystania z majątku narodowego oraz współdecydowania o sprawach publicznych.

Castel, nieżyjący już socjolog francuski, w książce Metamorfozy kwestii społecznej. Kronika pracy najemnej (wydanie francuskie 1995), dokładnie przeanalizował zmiany, jakim poddawana była rola pracownika najemnego. Ten proces dokonywał się etapami i polegał między innymi na wprowadzaniu przepisów, które regulowały zawieranie umów o pracę i jednocześnie miały za zadanie ochraniać pracowników najemnych, którzy zyskali pewną godność, choć - rzecz jasna - nie udało się ostatecznie zlikwidować ich ekonomicznego wyzysku. Jednak dzięki temu nad pracą najemną rozpostarty został parasol ochronny, a kapitalizm integrował - choć nierówno - dużą część robotników i urzędników z państwem (Zob. m.in. Dörre, 2015). Ewidentnym tego przykładem były wprowadzane przez Otto von Bismarcka w latach 80. XIX wieku świadczenia chorobowe, wypadkowe i tzw. renty starcze, adresowane do robotników wielkoprzemysłowych. Doświadczenia niemieckie śledzone były przez rządy ówczesnych państw uprzemysłowionych i - na skutek ich działań w przede dniu I wojny światowej - wprowadzono 
podobne rozwiązania $\mathrm{w}$ większości $\mathrm{z}$ nich, dając tym samym podwaliny pod przyszłe systemy zabezpieczenia społecznego. Już w czasach powojennej gospodarczej prosperity w krajach Europy Zachodniej, w okresie, który przeszedł do historii jako 30 wspaniałych lat (1945-1975), dokonał się rozwój systemu świadczeń społecznych i usług publicznych dostępnych dla wszystkich, wzrost płac robotniczych i urzędniczych oraz wykształciły się średnie warstwy społeczne. Od połowy lat 70. ubiegłego wieku zaczęła następować zmiana warunków pracy i życia. Dopiero w latach 90. kryzysy gospodarcze połączone z wysoką inflacją ujawniły zasadnicze problemy, które stały się zapowiedzią nadchodzącej prekaryzacji zarówno miejsc pracy, jak i samych pracowników. Dotyczyły one przede wszystkim krajów wysoko rozwiniętych, jednak recesja dotknęła także większość państw Europy Środkowo-Wschodniej, które przechodziły transformację ustrojową. Okazało się, że przejście z gospodarki socjalistycznej do kapitalistycznej nie będzie ani łatwe, ani bezbolesne dla większości pracowników. Receptą na uzdrowienie gospodarki stały się radykalne i przyspieszone neoliberalne reformy gospodarcze, które wpłynąć miały także wkrótce na stosunki pracy. Nałożyła się na to także kolejna w historii faza globalizacji, która oprócz nowych możliwości (rozwój technologii, łatwość przemieszczania się ludzi, towarów i idei - jednym słowem postęp cywilizacyjny), przyniosła także rozczarowania w postaci nowych nierówności. Jednak niepewność była też produktem woli politycznej (Bourdieu, 1998, s. 4). Wszystko to razem doprowadziło do sytuacji, w której stabilizacja i spójność społeczna stała się luksusem dostępnym jedynie dla nielicznych.

W tym sensie można powiedzieć, że polityka społeczna zatoczyła koło. Oczywiście nie chcę przez to powiedzieć, że znalazła się dokładnie w tym samym punkcie wyjścia. Przeobrażeniom uległa forma, system i sposób wynagradzania za pracę. Dało to początek debacie dotyczącej procesu pracy, ukształtowanej w nowoczesnym społeczeństwie przemysłowym. Efektem była między innymi teoria końca pracy Jeremy’ego Rifkina z lat 90. XX wieku. Podstawowe założenie głosiło, że praca traci swoje kluczowe znaczenie -kapitalizm utwardza się brutalnie i marginalizuje tych, którzy już nie mogą pozostawać w stosunkach pracy właściwych dla pracowników najemnych. Do pewnego stopnia przesadzona, ale propozycja ta pozwoliła jednak uświadomić ważny problem. Wbrew nazwie chodziło bowiem nie tyle o koniec pracy jako zajęcia, co o zmierzch pewnego porządku społecznego, ukształtowanego i opartego o swoisty „przymus” pracy. „W ciągu niecałego stulecia można się spodziewać topnienia masowego zatrudnienia w sektorze rynkowym praktycznie we wszystkich uprzemysłowionych państwach świata. (...) Inteligentne maszyny zastępują człowieka w niezliczonych 
zajęciach, skazując miliony pracowników umysłowych i fizycznych na kolejkę po zasiłek dla bezrobotnych lub nawet po darmowe posiłki" (Rifkin, 2003 s. 17).

Jest to jeden $\mathrm{z}$ wielu wariantów przemyśleń, jednak społeczna niepewność, która towarzyszy pracy, świadczy o tym, że wielka kwestia pracy, będąca przecież na początku synonimem kwestii społecznej, powróciła u progu XXI wieku (Castel, Dörre, 2009, s. 11), bowiem - jak zauważył Castel - „rola pracy najemnej jako czynnika integrującego społeczeństwo, staje się co najmniej wątpliwa” (Castel, 2008, s. 337).

Przypomnienie to było konieczne, gdyż pozwoli teraz przejść do zasygnalizowanych we Wstępie dwóch aspektów tytułowego zagadnienia.

\section{NIEPEWNOŚĆ PRACY - POWRÓT DO TRADYCYJNEJ KWESTII SPOŁECZNEJ}

Weźmy najpierw pod uwagę pierwszy ze wspomnianych aspektów. Chcąc określić pojęcie prekaryjnej pracy, trzeba najpierw ustalić i opisać specyficzne jej cechy. Wyróżnikiem prekaryjnej pracy jest wspomniana niepewność. Niewątpliwie wielką zasługą Gaya Standinga jest wprowadzenie do debaty publicznej terminów prekariat, prekariusz czy prekarna (praca). Jego książka z 2011 roku (wydanie oryginalne) traktująca o tym zagadnieniu jest obecnie wielokrotnie cytowana. Jednak warstwa ludzi pozbawiona perspektyw na stałą pracę i wynikających z niej uprawnień nie pojawiła się dopiero teraz. Zawsze byli ludzie, którzy nie mieli pewności co do trwałości wykonywanej przez nich pracy. Sytuacją "pracowników sezonowych”, ,tymczasowych”, , pracujących ubogich”, ,nadliczbowych” czy „ludzi zbędnych” zajmował się wspomniany już Castel. Dla Pierre’a Bourdieu dużo wcześniej „stało się jasne, że prekarność jest dziś wszechobecna” (Bourdieu, 1998, s. 1). Także Zygmunt Bauman posługiwał się określeniami ludzi-odpadów, ludzi-odrzutów, których produkcja ,jest nieuniknionym skutkiem modernizacji i nieodłącznym składnikiem nowoczesności; nieuchronnym efektem ubocznym zaprowadzania ładu (...) i postępu gospodarczego" (Bauman, 2004, s. 13). Ulrich Beck z kolei wprowadził termin społeczeństwa ryzyka, w którym nowoczesne społeczeństwo narażone jest na nieokreślone niebezpieczeństwa, powodujące życie w niepewności i ciągłym strachu, także przed utratą pracy, albo w ogóle brakiem możliwości wejścia na rynek pracy (Beck, 2004).

Prekariat jako przedmiot badań obecny jest zatem w debacie naukowej i społecznej już od co najmniej lat 80 . XX wieku, odzwierciedlając zmiany społeczne 
w odniesieniu do tego, co zwykliśmy określać jako typowe czy normalne warunki pracy. Jednak „chociaż nie ulega wątpliwości, że praca w społeczeństwach zorientowanych na dobrobyt podlega coraz większej elastyczności i niestabilności, to zakres i przyczyny tego rozwoju podlegają dyskusji”" (Marchart, 2013, s. 9).

Co wiemy o doświadczeniach tych, którzy na co dzień stykają się z niepewnością w związku z pracą, czyli samych prekariuszy? Problem z prekariatem polega na tym, że nie jest to grupa jednorodna praktycznie pod żadnym względem - „prekariat nie składa się z osób o identycznym życiorysie” (Standing, 2014, s. 189). Prekariusze są bowiem zróżnicowani zarówno ekonomicznie, politycznie i społecznie, a sam problem dotyczy większości z nas, „jeśli wydarzy się jakiś wypadek albo kryzys pozbawi nas poczucia bezpieczeństwa" (Ibidem, s. 137).

Klaus Dörre, odwołując się do szerokiej koncepcji prekaryzacji autorstwa Castela oraz na podstawie badań empirycznych, przedstawił model, w którym pracownicy zostali przypisani do trzech odmiennych stref i sklasyfikowani w zależności od charakteru i formy pracy. Pierwsza to sfera integracji (Zone der Integration), do której należą pracownicy stale zatrudnieni na czas nieokreślony i z tego tytułu objęci zabezpieczeniem społecznym; zatrudnieni w elastycznych formach, których ryzyko takiego zatrudnienia równoważy subiektywne poczucie zyskania wolności, oraz pracownicy, których miejsca pracy są zagrożone. Strefę wykluczenia (Zone der Entkoppelung) stanowią zarówno bezrobotni poszukujący pracy, jak i długotrwale bezrobotni młodzi ludzie, wykonujący dorywcze prace w nieformalnej sieci społecznej, w rodzinie i sąsiedztwie. Większość bezrobotnych chce jednak znaleźć pracę i jest na to gotowa, nawet jeśli jest to równoznaczne z zatrudnieniem, które nie zapewnia im dochodu wyższego od zasiłku i jest na niepewnych warunkach. Wreszcie strefa niepewności (Zone der Prekarität) oznacza różne jej odmiany: jedni mogą traktować prekarne zajęcia jako szansę wejścia i utrzymania się na rynku pracy, dla innych będzie to już stały układ, wreszcie są też i tacy, którzy mogą być nawet zadowoleni z takiego stanu rzeczy (Dörre, 2009, s. 48 i n.).

Mamy zatem do czynienia ze złożoną strukturą społeczną, a co za tym idzie, odmiennymi konsekwencjami, rzutującymi na poszczególne biografie. Jednocześnie definicje prekariatu określają to, co odróżnia prekariusza od nie-prekariusza. Ten ostatni objęty jest normalnym stosunkiem pracy, które definiuje się poprzez stałe zatrudnienie $\mathrm{z}$ odpowiednim wynagrodzeniem; prawa i gwarancje socjalne oraz prawo pracy; uregulowane godziny pracy; integrację zawodową oraz wykonywanie poleceń wynikających z umowy o pracę (Häfele, 
Greussing, 2008, s. 22). Natomiast prekaryjne zajęcia niezależnie od tego, kto je wykonuje, mają wspólny mianownik, który można sprowadzić do braku tych podstawowych cech, które są przypisane do stałej etatowej pracy. A zatem brak pewności, czy kontrakty zostaną przedłużone, a co za tym idzie - brak regularnych dochodów, które nie są w stanie zabezpieczyć egzystencji, gdyż najczęściej płaca jest niska; brak ochrony przed ryzykami społecznymi, takimi jak bezrobocie, choroby, wypadek, wiek; brak lub znaczne ograniczenie praw pracowniczych i tożsamości zawodowej.

Stereotypowe widzenie prekariusza ukazuje człowieka z niskim wykształceniem i kwalifikacjami lub ich brakiem, w związku z czym zmuszonego godzić się na każde warunki zatrudnienia. Skądinąd, choć jest to do pewnego stopnia uproszczone postrzeganie zjawiska, to jednak - jak wynika choćby między innymi z raportu opracowanego przez Europejski Instytut Równości Płci - brak wykształcenia sprzyja prekaryjnej pracy. Problem niepewnej pracy dotyczy ludzi z niskimi kwalifikacjami (wykształcenie podstawowe) zarówno kobiet, jak i mężczyzn. Jednak to kobiety zdominowały zajęcia prekaryjne. Także ludzie młodzi, którzy wcześnie opuścili szkołę, mają o wiele mniejsze szanse na etat niż starsi (Gender, skills..., 2017, s. 22 i n.). W rzeczywistości egzystencjalnej niepewności, jaka stała się udziałem wielu pracowników, współtowarzyszy wykształcenie nieadekwatnie wysokie do charakteru wykonywanej pracy. Można wymienić przedstawicieli wielu zawodów, które nie będą kojarzyć się z niepewnością, właśnie z uwagi na posiadane kwalifikacje i wykształcenie a także społeczny odbiór. Są to dziennikarze, tzw. wolni strzelcy, pracownicy szeroko pojętej kultury, przedsiębiorcy, często pozorni, bo stojący na czele jednoosobowych firm, zatrudnieni w coraz bardziej rozwijającym się sektorze usług.

Bourdieu zwraca uwagę, że z prekarnością można spotkać się zarówno w sektorze prywatnym, jak i publicznym (Bourdieu, 1998, s. 1). Jako przykład weźmy środowisko uczelniane. Szkoły wyższe publiczne nie zatrudniają już „swoich” pracowników, wykonujących pewnie nie tak prestiżowe być może prace, ale ważne, by uczelnia mogła jednak funkcjonować - mam tu na myśli pracowników portierni, sprzątających itd. To wszystko często wykonują dziś właśnie firmy zewnętrzne, zatrudniające pracowników w ramach outsourcingu, który pozwala obniżać koszty pracy przez pracodawcę i zwalnia go z odpowiedzialności za pracownika. Osobną kategorię w strukturze uczelni stanowią doktoranci, którzy uczestniczą w badaniach, a przede wszystkim prowadzą zajęcia na takich samych prawach, jak etatowi pracownicy naukowo-dydaktyczni. Jednocześnie studiują, 
a zatem z punktu widzenia uczelni są traktowani, jak studenci, nie podlegają zatem kodeksowi pracy. Zatrudnianie pracowników naukowych przez uczelnie na umowy cywilnoprawne to kolejny przykład. Tylko już te wybrane przykłady pokazują, jak zróżnicowana jest to grupa.

Badanie koncepcji prekariatu odzwierciedla także to, jak sami ludzie mówią o swoim położeniu. Nie wszyscy bowiem wykonujący niepewne prace to wyłącznie ofiary rynku pracy (Standing, 2014, s. 53, 137). Jedni stają się prekariuszami z braku faktycznych innych możliwości, ale inni - przynajmniej w swoim odczuciu - mogą cenić sobie taki sposób wykonywania pracy jako bardziej odpowiadający ich sytuacji życiowej. Nie muszą więc odczuwać swojego położenia jako groźnego, choćby ze względu na wiek i odległą jeszcze perspektywę dojrzałości, starości i wszystkiego, co się z tym wiąże.

Zasadniczo jednak, co podkreśla Castel, „w centrum dzisiejszej kwestii społecznej ponownie znajdują się »bezużyteczni«, nadliczbowi, a wokół nich zagmatwany obszar sytuacji, które zostały ukształtowane przez krytyczne położenie prekariatu oraz niepewność kolejnego dnia i które świadczą o ponownym wystąpieniu masowej wrażliwości" (Castel, 2008, s. 401). Dlatego utrata pracy i malejące szanse na pracę wywoływać będą jednak częściej poczucie własnej bezużyteczności i przynależności do grona nadliczbowych.

\section{ROLA POLITYKI SPOŁECZNEJ W KREOWANIU PREKARIATU I PREKARNYCH MIEJSC PRACY}

To drugi ze wskazanych przeze mnie aspektów problemowych. Trudno takiej roli polityki społecznej nie dostrzegać. Wynika ona - w mojej ocenie - z dwóch ważnych powodów. Pierwszy - natury ogólnej - łączy się ze zmianami w obszarze gospodarki. Niejako w obronie polityki społecznej należałoby przyznać, że jest ona realizowana obecnie $\mathrm{w}$ pewnym określonym otoczeniu i z racji tego poddawana rozmaitym zewnętrznym naciskom, przed którymi nie jest w stanie się obronić. W XIX, i jeszcze w XX wieku, sytuacja była pod pewnymi względami prostsza. Państwo opiekuńcze, realizujące politykę społeczną, było państwem narodowym, w którym - np. w modelu niemieckim - korporatyzm pogłębiał solidaryzm narodowy, ale także go kreował. Zakładano, że to państwo odpowiada za wyzwania świata. Skończyło się to z początkiem lat 90. ubiegłego wieku wraz ze wspomnianymi na początku kryzysami ekonomicznymi, globalizacją i neoliberalnymi rozwiązaniami, sprowadzającymi wszystko do prywatyzowania 
i deregulacji, a co znalazło swoje apogeum w tzw. turbokapitalizmie ${ }^{1}$. Z jednej zatem strony państwo narodowe nie jest już zdolne do całkowicie samodzielnego prowadzenia polityki społecznej, jak bowiem ma to czynić, gdy to wielkie transnarodowe korporacje decydują o handlu, produkcji, podziale zysków. Państwo, w sytuacji, gdy gospodarka nie poddaje się już rozwiązaniom na poziomie krajowym, pozostaje z konsekwencjami natury społecznej, które próbuje rozwiązywać w ramach prowadzonej przez siebie polityki społecznej. $Z$ drugiej zaś strony widać dziś, że proste - jakby się mogło zdawać - neoliberalne recepty nie sprawdziły się w polityce społecznej. Nawet najwierniejsi przez ostatnie ćwierćwiecze wyznawcy tego rodzaju rozwiązań ewoluowali w swych poglądach i zwracają dziś uwagę na pewne negatywne ich przejawy².

Drugi powód - moim zdaniem - jest konsekwencją zaniku tego, co określa się jako solidaryzm społeczny. Dyskusja o prekariacie przenosi się tym samym na inną płaszczyznę. Prekarność we wszystkich jej odmianach to odmowa dostępu do podstawowych praw jednostki. Właśnie tu polityka społeczna sprzeniewierzyła się swojej klasycznej roli, polegającej na dążeniu do spójności społecznej. W krajach transformacji społecznej sytuacja była podwójnie trudna. Jak zauważa Dörre, „po kryzysie energetycznym w latach 1973-1974 w Zachodniej Europie - a potem, w wyniku upadku biurokratycznego socjalizmu państwowego, na Wschodzie - mieliśmy do czynienia ze stopniowym utowarowieniem tych obszarów i form życia, które niegdyś były pod ochroną. Wiązało się to przede wszystkim z komercjalizacją i prywatyzacją usług publicznych” (Dörre, 2015). Z kolei prywatyzacja czy ograniczanie dostępu do usług jest równoznaczna z odmową praw społecznych: prawa do emerytury, ubezpieczenia na wypadek bezrobocia, ubezpieczeń zdrowotnych, a w konsekwencji także praw politycznych (por. Marchart, 2013, s. 9). Sednem problemu wyalienowania politycznego jest to, że - jak zauważył Standing - „prekariat to pierwsza klasa ludzi pracujących, która zamiast $z$ czasem zyskiwać prawa - traci je. Traci prawa obywatelskie, kulturowe, społeczne i gospodarcze, które inne klasy przed nim wywalczyły. Kulturowe,

1 Przez turbokapitalizm rozumiem taki system, który w pogoni za zyskiem wyzbył się wszelkich hamulców moralnych.

2 Na przykład Jeffrey Sachs, doradca Leszka Balcerowicza z okresu transformacji, był później między innymi doradcą sekretarza generalnego ONZ do spraw Milenijnych Celów Rozwoju - międzynarodowych założeń, które miały na celu likwidację skrajnej biedy, chorób i głodu do 2015 roku. John Gray, autor książki Liberalizm i ideolog rządu Margaret Thatcher, twierdzi natomiast, że „idea globalnego wolnego rynku spocznie obok komunizmu w muzeum zbankrutowanych utopii" (Zob. Domosławski, 2003). 
bo prekariusze nie przynależą do dominującej społeczności. Polityczne, bo nie czują się reprezentowani przez partie. Socjalne, bo nie mają dostępu do gwarantowanych przez państwo przywilejów. I gospodarcze, bo nie mogą wykonywać wyuczonego zawodu" (Standing, 2015).

Jak twierdzi Vera Trappmann, przejście w Polsce od jednego systemu do drugiego, polegające na dostosowaniu się do reguł globalizacji, a zwłaszcza kapitalizmu opartego na rynkach finansowych, nie odbyło się przecież bez ofiar: utrata wielu miejsc pracy, bezrobocie strukturalne, a także ogromna bierność sporej grupy ludności to elementy biografii wielu współobywateli. Nowy system wyłączał z dobrobytu i bezpieczeństwa dużą część populacji, która nie była brana pod uwagę przez reformatorów Jednak po przystąpieniu do UE aktywna polityka rynku pracy także nie spełniła swojego celu, gdyż nie udało się osiągnąć integracji i reintegracji. Polityka aktywizacji zamiast zwalczać, to jeszcze pogłębiła niepewności. Często pomijany jest fakt, że część firm po prostu zmuszała pracowników do nielegalnej pracy, aby zaoszczędzić na składkach na ubezpieczenie społeczne. Pracownicy zaś w obawie przed utratą pracy godzili się na takie praktyki (zob. Trappmann, 2012, s. 168, 169).

Także inne rozwiązania, które miały przyczynić się do zmniejszenia bezrobocia, ostatecznie doprowadziły - wbrew założeniom - do zwiększenia poczucia niepewności związanej z pracą. Jako przykład posłużę się popularnym outsourcingiem i elastycznymi formami zatrudnienia. $\mathrm{W}$ obu przypadkach pojawia pewien problem. Czy outsourcing można utożsamić $\mathrm{z}$ budowaniem prekariatu? Jego założenia były przecież zupełnie inne. Pojawia się więc pytanie, czy ten mechanizm wynika z outsourcingu jako takiego, czy z prawa, które pozwala tak a nie inaczej zatrudniać ludzi, czy z braku odpowiedniej reakcji ze strony polityki społecznej, która poprzez zaniechanie tylko ten system wzmocniła? Generalnie sam problem nie tkwi także w elastycznych miejscach pracy, ale w nadużywaniu tej formy, jak ma to miejsce przede wszystkim w Polsce. Elastyczność w założeniu była alternatywą dla tych, którzy mieli trudności albo z wejściem na rynek pracy (młodzież), albo z powrotem na rynek pracy po czasowej dezaktywacji zawodowej (np. kobiety po urlopach macierzyńskich i wychowawczych). Niestety, w Polsce właśnie rozumienie elastyczności poszło w odmiennym od zamierzonego kierunku, przyczyniając się do powiększenia prekarnych miejsc pracy. Najbardziej rozpowszechnioną elastyczną formą zatrudnienia jest praca tymczasowa. Polska, by odwołać się do statystyki, jest na 3. miejscu w Europie, jeśli chodzi o liczbę agencji pracy tymczasowej. Jak podaje Krajowy Rejestr Agencji Zatrudnienia, w 2013 roku pracodawcy mogli korzystać z 4.540 agencji, a już rok 
później liczba ta wzrosła do 5.516, by na początku 2018 wynieść około 8.921. To, co miało stać się ułatwieniem dla niektórych, stało się niemal normą ${ }^{3}$. Nawiasem mówiąc, postrzeganie tych agencji jako pełnoprawnych instytucji rynku pracy w programach rynku pracy wydaje się być nadinterpretacją.

W tej sytuacji trudno o spójność, jeśli prekariat traktujemy jako niejednorodną grupę pracowników, o różnym poziomie wykształcenia, kwalifikacji i wykonywanego zawodu. Nie łączy ich wspólnota interesów - ani politycznych, ani ekonomicznych. W tym sensie prekariat nie zastępuje proletariatu, który już dawno zniknął z porządku społeczno-politycznego. Niepewność, brak poczucia bezpieczeństwa oraz zwiększające się nierówności strukturalne nie doprowadziły jak dotąd - mimo protestów w Hiszpanii, Grecji czy Wielkiej Brytanii - do wystąpień na masową skalę, które w efekcie spowodowałyby powstanie poważnych i silnych ruchów pracowniczych.

\section{ZAKOŃCZENIE}

Większość dotychczasowych dyskusji na temat prekariatu miało miejsce w społeczeństwach zachodnich. Najpierw był to przedmiot refleksji w naukach społecznych, następnie politycznego namysłu. W latach 90. XX wieku w całej Europie nastąpiło ogromne przyspieszenie zmian społecznych i gospodarczych, które podały w wątpliwość dotychczasowe aksjomaty, takie jak między innymi: nieograniczony wzrost gospodarczy, stabilność pracy i zabezpieczeń społecznych, trwałość państw narodowych, realizujących z powodzeniem w latach powojennych politykę społeczną. W tym czasie załamał się także system socjalistyczny, stawiając kraje transformacji systemowej przed zupełnie nowymi wyzwaniami, wynikającymi z wprowadzenia gospodarki rynkowej. Niepewność pracy stała się jednym $\mathrm{z}$ nich.

Rozważając problem prekariatu, który jest odzwierciedleniem tych zmian gospodarczych, politycznych i społecznych, należy wziąć pod uwagę następujące sprawy, które wymienię tu w dowolnej kolejności:

1. Obraz prekariatu kształtują indywidualne doświadczenia każdego z pracowników.

3 W 2017 roku weszły w życie zmiany, dotyczące weryfikacji działalności zatrudnienia, 1 stycznia 2018 roku zaś weryfikacji odprowadzania składek do ZUS-u. Za jakiś czas będziemy mogli się przekonać, czy podniesie to standardy zatrudnienia i wpłynie na sytuację pracowników. 
2. Prekariat we wszelkich jego odmianach to problem systemowy, wygenerowany przez rynek, ale i państwo. To państwo kreuje prawo, nawet jeśli czyni to pod dyktando rynku.

3. Polityka społeczna $\mathrm{z}$ kolei nie jest w stanie na poziomie krajowym rozwiązać - tak jak miało to miejsce w przeszłości - problemów, które są wynikiem globalnych procesów.

Czy jest zatem wyjście z tej sytuacji? Na płaszczyźnie praktycznej problem prekariatu, będącego nową formą nierówności społecznych, wymaga stworzenia rozwiązań na poziomie międzynarodowym, na przykład prawnych, które by ucywilizowały działania wielkich ponadnarodowych korporacji, co się już dzieje. Jak jednak się okazuje, to nie tylko prywatne przedsiębiorstwa korzystają z pracowników o niepewnym statusie, także pracodawcy z sektora publicznego nie ustępują im pola. To, co miało być ułatwieniem (elastyczność, samozatrudnienie), zostało potraktowane jako normalne stosunki pracy. Zapanowała w tym względzie zupełna zgodność, niezależnie od sektora, dlatego wszelkie działania odwracające te tendencje są niezbędne.

Z kolei na poziomie teorii wymaga to ponownego przedyskutowania podstawowych praw jednostki. W tym znaczeniu koncepcja prekariatu przekłada się na politykę społeczną, przypominając, czym powinna się w swej istocie zajmować.

\section{BibLIOGRAFIA:}

Bauman, Z. (2004). Życie na przemiał. Kraków: Wydawnictwo Literackie.

Beck, U. (2004). Społeczeństwo ryzyka. W drodze do innej nowoczesności. Warszawa: Wydawnictwo Naukowe „Scholar”.

Bourdieu, P. (1998). Prekarität ist überall. W: Gegenfeuer. Wortmeldungen im Dienste des Widerstands gegen die neoliberale Invasion. Konstanz: UVK. Pobrane z: http://www. forschungsnetzwerk.at/downloadpub/bourdieu\%20-\%20prekaritaet.pdf.

Castel, R. (2008). Die Metamorphosen der sozialen Frage. Eine Chronik der Lohnarbeit. Konstanz: UVK Verlagsgesellschaft $\mathrm{mbH}$.

Castel R., Dörre K. (2009). Einleitung. W: Prekarität, Abstieg, Ausgrenzung. Die soziale Frage am Beginn des 21. Jahrhunderts. Frankfurt-New York: Campus Verlag.

Domosławski, A. (2003). Niecnoty turbokapitalizmu. Pobrane z: http://wyborcza. $\mathrm{pl} / 1,76842,1315054 . h t m l$.

Dörre, K. (2009). Prekariat im Finanzmarkt-Kapitalismus. W: Castel, R., Dörre, K., (Hg.), Prekarität, Abstieg, Ausgrenzung. Die soziale Frage am Beginn des 21. Jahrhunderts. Frankfurt-New York: Campus Verlag.

Dörre, K. (2015). Prekariat jest tak stary, jak kapitalizm. Pobrane z: http.//krytykapolityczna.pl/gospodarka/dorre-prekariat-jest-tak-stary-jak-kapitalizm/. 
Esping-Andersen, G. (1999). Social Foundations of Postindustrial Economies, Oxford: University Press.

Gender, skills and precarious work in the EU. Research note. (2017). Vilnius: European Institute for Gender Equality. Pobrane z: http.//eige.europa.eu/sites/default/files/ documents/ti_pubpdf_mh0217250enn_pdfweb_20170503163908.pdf.

Häfele, E., Greussing, K. (2008). Schicksal Prekarität? Maßnahmen für Vorarlberg. Pobrane z: https://media.arbeiterkammer.at/vbg/PDF/prekaritaet_endbericht.pdf.

Krajowy Rejestr Agencji Zatrudnienia. Pobrane z: www.stor.praca.gov.pl/portal/\#/kraz/ statystyki.

Lampert, H. (1998). Lehrbuch der Sozialpolitik. Berlin-Heidelberg: Springer-Verlag.

Marchart, O. (2013). Die Prekarisierungsgesellschaft. Prekäre Proteste. Politik und Ökonomie im Zeichen der Prekarisierung. Bielefeld: Transkript Verlag.

Marshall, T.H. (1950). Citizenship and social class. W: Marshall, T.H., Bottomore, T. (2009). Citizenship and social class. London: Pluto Press.

Rifkin, J. (2003). Koniec pracy. Schyłek siły roboczej na świecie i początek ery postrynkowej. Wrocław: Wydawnictwo Dolnośląskie.

Standing, G. (2014). Prekariat. Nowa niebezpieczna klasa. Warszawa: PWN. Standing, G. (2015). Nowa niebezpieczna klasa siegnie po władzę? „Nowa Konfederacja”. Pobrane z: https.//nowakonfederacja.pl/nowa-niebezpieczna-klasa-siegnie-po-wladze/.

Trappmann, V. (2012). Flexibilisierung und Prekarisierung: Arbeitsmarkt(-politik) in Polen unter dem Einfluss von Transformation und Europäischer Integration. W: Scherschel, K., Streckeisen, P., Krenn, M. (Hg.) Neue Prekarität. Die Folgen aktivierender Arbeitsmarktpolitik - europäische Länder im Vergleich. Frankfurt am Main-New York: Campus Verlag. 